\title{
PENERAPAN MODEL PEMBELAJARAN TEAMS GAMES TOURNAMENT BERBANTU MEDIA ULAR TANGGA UNTUK MENINGKATKAN KETERAMPILAN COLLABORATIVE SISWA SD
}

\author{
Stefani Galih Febriana ${ }^{1}$, Mawardi ${ }^{2}$, Suhandi Astuti ${ }^{3}$ \\ 1,2,3 Pendidikan Guru Sekolah Dasar FKIP UKSW
}

kotaksuratfani@gmail.com mawardi@staff.uksw.edu suhandi.astuti70@gmail.com

\begin{abstract}
Abstrak
Permasalahan yang terdapat dalam proses pembelajaran Matematika kelas 5 di SD Negeri Salatiga 02 adalah keterampilan Collaborative siswa masih rendah dan berdampak pada rendahnya hasil belajar siswa. Pada studi awal menemukan bahwa $76 \%$ siswa tingkat keterampilan Collborativenya masih rendah. Berdasarkan permasalahan tersebut maka peneliti melakukan penelitian mengunakan metode penelitian tindakan kelas dengan model Teams Games Tournament berbantu media ular tangga. Penelitian ini menggunakan instrumen pengumpulan data angket untuk mengukur keterampilan Collaborative siswa. Hasil penelitian, menunjukkan belum terjadi peningkatan keterampilan Collaborative kategori tinggi pada siklus I. Setelah diperbaiki dan dilakukan pengukuran dalam siklus II, terjadi peningkatan keterampilan Collaborative sebesar 13,4\%. Berdasarkan uraian di atas dapat disimpulkan bahwa penelitian ini berhasil karena model Teams Games Tournament berbantu media ular tangga dapat meningkatkan keterampilan Collaborative pada siklus II.
\end{abstract}

Kata Kunci: Teams Games Tournament, Media Ular Tangga ${ }_{s}$ Keterampilan Collaborative.

\begin{abstract}
There are problems in the process of learning Mathematics grade 5 in SD Negeri Salatiga 02 Collaborative skills is still low and the students have an impact on the low results of student learning. On preliminary study found that $76 \%$ of students Collborativenya skill level is still low. Based on these problems then the researchers conducting research using research methods a class act with a model of its Teams Games Tournament berbantu snake media ladder. This research uses data collection instruments for measuring the skills now Collaborative students. Results of the study, suggesting an increase in skills yet Collaborative category i. cycle high Once repaired and carried out measurements in cycle II, an increase in Collaborative skills of $13.4 \%$. Based on the above description it can be concluded that this model works because research Teams Games Tournament ladder snake media berbantu can improve the skills of the Collaborative cycle II.
\end{abstract}

Keywords: Teams Games Tournament, Ladder Snakes, Media Collaborative Skills. 


\section{PENDAHULUAN}

Berdasarkan pengamatan dan wawancara kepada wali kelas 5 SD Negeri Salatiga 02 peserta didik yang terdapat di sekolah tersebut khususnya untuk kelas 5 pada pelajaran matematika siswa tidak tertarik dengan pelajaran Matematika karena membosankan, siswa kurang mampu mengaitkan konsep-konsep matematika yang dipelajarinya. Mereka hanya menghafal konsep-konsep matematika bukan belajar untuk memahami konsep-konsep matematika. Siswa kesulitan dalam memecahkan soal-soal matematika. Pemahaman konsep yang masih rendah ini mengakibatkan hasil belajar yang rendah juga. Serta untuk tingkat kerjasama siswa di dalam berkelompok masih agak rendah.

Dari penjelasan diatas peneliti mencari model dan media yang sesuai pembelajaran dalam kelas supaya dapat terjadinya peningkatan pembelajaran dalam kelas 5 . Cara meningkatkan keterampilan Collaborative siswa yang akan berdampak pada hasil belajar siswa maka peneliti menggunakan model Teams Games Tournament berbantu media ular tangga.

PTK ini dapat bermanfaat bagi guru, yaitu dapat menggunakan PTK sebagai acuan untuk hasil belajar meningkat agar tujuan pembelajaran tercapai. Siswa diharapkan dengan PTK ini bias meningkatkan hasil belajarnya dengan lebih baik dan dapat aktif di dalam pembelajaran dalam kelas. Sekolah bias menjadi panduan untuk bias memperbaiki hasil belajar siswa.

Peneliti berupaya agar siswa dengan tingkat Collaborative siswa yang rendah dapat meningkat dan membawa dampak pada hasil belajar siswa. Hasil belajar ini dijadikan sebuah patokan guru dalam mencapai tujuan pembelajaran dalam kelas. Siswa mendapatkan hasil belajar yang baik maka pembelajaran dalam kelas tujuannya akan tercapai.

Tujuan dari penelitian ini adalah untuk meningkatkan keterampilan Collaborative siswa pada mata pelajaran Matematika melalui model pembelajaran kooperatif tipe Teams Games Tournament berbantuan media ular tangga siswa kelas 5 SD Negeri
Salatiga 02 Semester II tahun pelajaran 2017/2018

Kerjasama antara siswa dalam kegiatan belajar menurut Harmin (dalam Isjoni, 2009: 36) adalah aktivitas yang dapat memberikan pengalaman kepada siswa karena akan lebih banyak mendapatkan kesempatan dalam hal berbicara, berinisiatif, berpendapat. Sedangkan Sutikno (2012: 212) menjelaskan bahwa untuk mencapai hasil belajar yang optimal, siswa perlu dibiasakan untuk menggunkaan komunikasi banyak arah atau kounikasi sebagai transaksi sebagai bentuk kerjasama mereka dalam upaya memahami materi. Dari kedua pendapat diatas menyatakan bahwa siswa sangat perlu untuk bekerjasama agar dapat memperoleh banyak pengalaman.

Beberapa manfaat kerjasama menurut Sunarto (dalam Zulkarnain, 2013: 28) antara lain (1) antara individu akan bekerjasama untuk saling membantu; (2) permasalahan yang terjadi akan teratasi dengan baik dan mengurangi beban pekerjaan yang besar; (3) saling memberikan masukan satu dengan yang lainnya.

Model pembelajaran kooperatif tipe teams games tournament melibatkan untuk siswa lebih aktif di dalam proses pembelajaran, yaitu siswa memiliki kebebasan untuk berinteraksi dan mengemukakan pendapatnya. Selain itu, model Teams Games Tournament ini menggunakan game atau permainan akademik antar kelompok dimana siswa akan berebut untuk mendapatkan nilai dan penghargaan yang baik dalam kelompoknya.

Model pembelajaran kooperatif tipe TGT. Isjoni (2010: 83) menyatakan bahwa model pembelajaran TGT adalah salah satu tipe pembelajaran kooperatif yang menempatkan siswanya ke dalam kelompokkelompokbelajar beranggotakan 5 sampai 6 orang siswa yang memiliki kemampuan, jenis kelamin dan suku atau ras yang berbeda. Perbedaan signifikan yang menjadikan model pembelajaran kooperatif TGT ini menjadi sangat menarik karena di akhiri dengan game. 
Karakteristik Teams Games Tournament yaitu siswa belajar dalam kelompok kecil dimana dalam proses pembelajaran terdapat permainan atau turnamen yang nantinya akan ada penghargaan kelompok. Aktivitas belajar dengan permainan yang dirancang dalam pembelajaran kooperatif model TGT memungkinkan siswa dapat belajar lebih rileks disamping menumbuhkan tanggung jawab, percaya diri, menghargai sesama, disiplin, kompetetif, sopan, kreatif, inovatif, rasa ingin tahu, dan keterlibatan belajar seluruh siswa.

TGT juga banyak sekali digunakan sebagai bahan penelitian PTK karena TGT lebih terlihat di dalam kelompok untuk bekerjasama. Terdapat lima langkah model pembelajaran kooperatif tipe Teams Games Tournament yang dapat dilakukan di dalam proses pembelajaran dengan model Teams Games Tournament yaitu (1) Penyajian kelas pada awal pembelajaran, guru menyampaikan materi dalam penyajian kelas atau sering juga disebut dengan presentasi kelas; (2) Belajar dalam kelompok, guru membagi murid-murid ke dalam kelompokkelompok berdasarkan kriteria kemampuan peserta didik, jenis kelasmin, ras, dan suku; (3) Permainan, games atau permainan dari pertanyaan-pertanyaan yang relevan dengan materi dan dirancang untuk menguji pengetahuan yang didapat peserta didik dri penyajian kelas dan belajar kelompok; (4) Pertandingan atau lomba (Tournament), struktur belajar di mana game atau permainan terjadi; (5) Penghargaan kelompok, skor yang didapatkan kelompok dijumlahkan dan diambil rata-ratanya.

Model Teams Games Tournament ini nemiliki kelebihan bahwa model TGT tidak hanya membuat peserta didik yang cerdas tinggi menonjol dalam pembelajaran saja tetapi peserta didik juga mendapatkan peranan penting dalam kelompoknya. Dalam model pembelajaran ini, juga dapat membuat peserta didik bersemangat dalam mengikuti pembelajaran karena ada kegiatan permainan atau turnamen dalam model ini.

Marwadi (2018: 29) mengatakan bahwa model pembelajaran sangat berkaitan dengan media pembelajaran untuk mengingkatkan kegiatan pembelajaran. Media pembelajaran merupakan segala sesuatu yang dapat digunakan sebagai sarana pembelajaran di kelas untuk membantu kegiatan pembelajaran dalam menyampaikan materi yang disampaikan. Menurut Briggs berpendapat bahwa media adalah segala alat fisik yang dapat merangsang siswa untuk belajar.

Dari beberapa definisi diatas dapat disimpulkan mengenai pengertian media pemmbelajaran. Media pembelajaran adalah suatu perantara yang digunakan oleh pendidik/guru untuk menyalurkan pesan atau informasi kepada siswanya sehingga siswa tersebut dapat terangsang ketika mengikuti kegiatan pembelajaran. Dapat dikatakan pula media pembelajaran dapat memudahkan siswa untuk untuk menerima pembelajaran yang disampaikan oleh guru.

Kreatifitas guru dituntut ketika kondisi sekolah minim dengan sarana dan prasarana, salah satu kreatifitas guru yaitu dengan menyediakan media pembelajaran, guru harus mampu membuat media pembelajaran yang inovatif untuk mendukung proses pembelajaran di kelas. Menurut Arsyad (2011:12) Media pembelajaran adalah sebuah alat yang berfungsi untuk menyampaikan pesan pembelajaran. Media pembelajaran diharapkan mamp uuntuk meningkatkan keinginan belajar atau motivasi belajar siswa.

Kelebihan media pembelajaran permainan ular tangga yaitu (1) siswa belajar sambil bermain, (2) siswa tidak belajar sendiri melainkan harus berkelompok dengan teman-temannya, (3) memudahkan siswa belajar karena dibantu dengan permainan ular tangga, (4) tidak memerlukan biaya mahal untuk media permainan ular tangga.

Di dalam permainan ular tangga berisi soal-soal padasetiap kertas. Siswa diminta untuk menjawab soal-soal tersebut. Sistem permainan ular tangga dapat dirincikan sebagai berikut (1) Tiap kelompok permainan terdiri5-6 orang; (2) perwakilan kelompok maju ke depan untuk mengambil soal di guru; (3) permainan dimulai ketika guru sudah membacakan soal; (4) semua kelompok mencari jawabannya dan 
kelompok siapa yang paling cepat menjawab. Jika jawabannya benar kelompok tersebut akan melangkah dalam permainan ular tangga; (5) kelompok melangkah sesuai dengan ketentuan soal yang sudah diberikan; (6) Permainan dikatakan menang dengan skor tertinggi.

\section{METODE}

Penelitian ini menggunakan jenis Penelitian Tindakan Kelas (PTK). Menurut Kemmis dan McTaggart (dalam Arikunto 2008: 16) mengatakan bahwa PTK merupakan desain penelitian yang menggunakan siklus. Siklus ini tidak berlangsung satu kali, tetapi beberapa kali hingga tercapai tujuan yang diharapkan.

Penelitian ini dimaksudkan untuk mengungkapkan permasalahan dalam pembelajaran Matematika melalui model pembelajaran Teams Games Tournament yang berbantuan media ular tangga dalam pembelajaran agar dapat meningkatkan keterampilan Collaborative siswa.

Subjek dalam penelitian ini adalah siswa kelas 5 SD Negeri Salatiga 02 sejumlah 46 siswa. Penelitian ini dilaksanakan pada semester II tahun pelajaran 2017/2018.

Prosedur penelitian yang dierapkan dalam penelitian ini terdiri atas empat tahapan antara lain; (1) perencanaan; (2) pelaksanaan; (3) pengamatan; (4) refleksi.

Dalam penelitian ini, untuk mengumpulkan data selama proses pembelajaran peneliti menggunakan alat pengumpulan data berupa: (1) Observasi, untuk mengetahui permasalahan yang dihadapi oleh guru dan siswa; (2) Angket, digunakan untuk mengetahui seberapa jauh keterampilan Collaborative siswa; (3) Tes digunakan untuk melihat hasil belajar siswa; (4) Teknik Dokumentasi.

Dalam hal ini, peneliti menggunakan teknik analisis data dengan cara deksriptif kualitatif dan kuantitatif. Deksripsi kualitatif dan kuantitatif dalam penelitian ini digunakan untuk untuk menggambarkan keterampilan Collaborative siswa. Teknik analisis data terhadap beberapa permasalahan tersebur meliputi beberapa tahapan yaitu tahap pengumpulan data, reduksi data, penyajian data dan penyimpulan data. Indikator keberhasilan terjadinya jika ada peningkatan persentase keterampilan Collaborative siswa pada kategori tinggi pada siklus I ke siklus II.

\section{HASIL DAN PEMBAHASAN Hasil}

Pada pra siklus sebelum diadakan penelitian tindakan di kelas 5 SD Negeri Salatiga 02 diketahui bahwa sebagian besar dari jumlah siswa yaitu 35 siswa (76\%) keterampilan Collaborative siswa masih berada di kriteria rendah, sebanyak 11 siswa (24\%) berada pada kriteria sedang, dan belum ada siswa yang mencapai pada kriteria kategori tinggi..

Siswa masih kurang untuk bekerjasama di dalam kelompok. Masih banyak siswa yang lebih suka bekerja secara sendiri dan kurang memperhatikan di dalam kelompoknya. Dampaknya adalah siswa tidak terlalu dapat bekerjasama dengan baik hal tersebut berdampak lanjutan pada hasil belajar siswa. Siswa diharapkan pada pembelajaran kali ini dengan menggunakan model dan media pembelajaran yang menarik dapat meningkatkan keterampilan Collaborative siswa.

Kondisi rendahnya keterampilan Collaborative siswa berdampak pada hasil belajar siswa. Hal ini ditunjukkan pada hasil belajar siswa yang dapat dilihat pada nilai ulangan yaitu masih ada 16 siswa atau $35 \%$ yang belum mencapai KKM 70 .

Data tentang angket keterampilan Collaborative siswa diambil setalah melakukan pembelajaran pada akhir siklus I, instrumen angket terdiri dari 15 item. Dari analisis angket diperoleh data keterampilan Collaborative siswa. Kategori rentang skor antara 15-30 berarti kategori rendah, 31-46 sedang, 47-60 tinggi. Hasil keterampilan Collaborative siswa diperoleh dari hasil angket sebagai berikut: 4 siswa atau 9\% berada pada kategori rendah, lalu 11 siswa atau 24\% masih berada pada kategori rendah, dan sudah ada terjadi peningkatan pada kategori tinggi yaitu sebanyak 31 siswa atau $67 \%$

Siklus II

Keterampilan Collaborative 
Data tentang angket keteranpilan Collaborative siswa diambil setalah melakukan pembelajaran pada akhir. Hasil angket diperoleh dari hasil keterampilan Collaborative siswa sebagai berikut: sudah tidak ada siswa yang berada pada kategori rendah, sedangkan pada kategori sedang masih tetap 11 siswa atau 24\%, dan 35 siswa atau $76 \%$ pada kategori tinggi.

Perbandingan hasil penelitian keterampilan Collaborative siswa pada pra siklus, siklus I, dan siklus II setelah dilakukan pengamatan saat proses pembelajaran data diperoleh sebagai berikut:

Tabel 2. Perbandingan Keterampilan Collaborative Siswa Pra Siklus, Siklus I, dan Siklus II

\begin{tabular}{ccccc}
\hline No & Kategori & $\begin{array}{c}\text { Pra } \\
\text { Siklus }\end{array}$ & S.I & S.II \\
\hline 1. & Tinggi & - & $68 \%$ & $76 \%$ \\
\hline 2. & Sedang & $24 \%$ & $24 \%$ & $24 \%$ \\
3. & Rendah & $76 \%$ & $9 \%$ & - \\
\hline
\end{tabular}

Berdasarkan data di atas pada siklus I terjadi kenaikan keterampilan Collaborative siswa pada kriteria sangat tinggi 31 siswa atau 67\%. Pada siklus II terjadi peningkatan keterampilan Collaborative yang mencapai 35 siswa atau $876 \%$. Hal ini dapat disimpulkan bahwa model TGT berbantuan media ular tangga dapat meningkatkan keterampilan Collaborative siswa.

Berdasarkan tabel 2 terlihat bahwa dari pra siklus, siklus I, dan siklus II terjadi peningkatan keterampilan Collaborative siswa pada kategori tinggi. Perbandingan keterampilan Collaborative siswa menggunakan model Teams Games Tournament dapat dilihat melalui gambar 1.

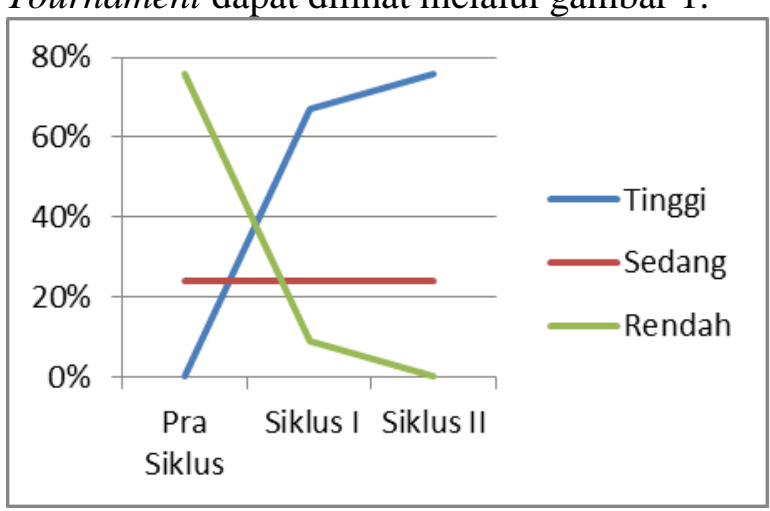

Gambar 1.

\section{Perbandingan Keterampilan Collaborative Pra Siklus, Siklus I, dan Siklus II \\ Keterampilan Collaborative siswa juga berdampak pada hasil belajar siswa yang dapat dilihat pada tabel 2 .}

Tabel 2. Perbandingan Hasil Belajar Siswa Pra Siklus, Siklus I, dan Sikus II

\begin{tabular}{lllll}
\hline No & $\begin{array}{c}\text { Keterampilan } \\
\text { Collaborative } \\
\text { Siswa }\end{array}$ & $\begin{array}{c}\text { Pra } \\
\text { Siklus }\end{array}$ & S.I & S.II \\
\hline 1. & Tertinggi & 90 & 100 & 100 \\
2. & Terendah & 26 & 35 & 45 \\
3. & Rata-rata & 64,84 & 81,08 & 90.76 \\
\hline
\end{tabular}

\section{Pembahasan}

Keterampilan Collaborative siswa pada mata pelajaran Matematika yang diukur melalui angket menujukkan hasil pada pra siklus belum mencapai pada kategori tinggi. Setelah dilakukan pembelajaran dengan menggunakan model Teams Games Tournament berbantuan media ular tangga terjadi peningkatan. Pada siklus I sudah terjadi peningkatan $67 \%$ siswa sudah mencapai pada kategori tinggi. Kemudian ditingkatkan lagi pada siklus II tetapi hasil keterampilan Collaborative siswa pada siklus II hasil yang didapatkan telah terjadi kenaikan lagi yaitu 76 pada kategori tinggi.

Dalam penelitian ini terdapat satu variable yaitu keterampilan Collaborative siswa. Menurut suprihanto (dalam Sulkarnain, 2013: 4) kerjasama merupakan interaksi dalam kelompok dengan cara-cara tertentu, sehingga perilaku atau prestasi seseorang mempengaruhi prestasi atau perilaku orang lain untuk mencapai tujuan tertentu. Pendapat tersebut diperkuat oleh pernyataan Sutikno (2012: 212) yang mengatakan, untuk mencapai hasil belajar yang optimal, dianjurkan agar guru membiasakan diri menggunakan komunikasi banyak arah atau komunikasi sebagai transaksi, yaitu komunikasi yang tidak hanya melibatkan interkasi dinamis antara siswa yang satu dengan siswa yang lainnya dalam bentuk kerjasama mereka dalam upaya memahami suatu materi yang dipelajari.

Penelitian yang dilakukan oleh peneliti juga didukung oleh Teams Games Tournament yang berhasil menigkatkan keterampilan Collaborative siswa sejalan 
dengan penelitian Fifi Fitriana Sari (2012: 92) tentang Implementasi Model Pembelajaran Kooperatif Tipe Teams Games Tournament (TGT) dalam Pemecahan Masalah di Pelajaran Matematika kelas 5 SD yang menunjukkan bahwa dapat meningkatkan tingkat kerjasama siswa dalam pemecahan masalah soal Matematika. Temuan ini didukung juga oleh temuan penelitian Rudiansyah (2010: 27) tentang penerapan model Cooperative learning tipe Teams Games Tournament dalam pembelajaran Matematika. Demikian juga temuan Rini Hadiyanti (209: 106) tentang keefektifan pembelajaran kooperatif Teams Games Tournament terhadap kemampuan kerjasama siswa.

Dari uraian di atas maka dapat diperoleh hasil penelitian bahwa penerapan model pembelajaran TGT berbantuan media ular tangga dapat meningkatkan ketreampilan Collaborative siswa yang dapat dilihat pada siklus I dan siklus II terjadi peningkatan.

\section{SIMPULAN DAN SARAN}

Berdasarkan hasil pembahasan di atas, maka dapat disimpulkan bahwa penerapan model Cooperative tipe Teams Games Tournament berbantu media ular tangga dapat meningkatkan keterampilan Collaborative siswa pada matapelajaran Matematika kelas 5 SD Negeri Salatiga 02 semester II tahun pelajaran 2017/2018.

Berdasarkan hasil penelitian yang telah dilakukan, penerapan model pembelajaran kooperatif tipe TGT berbantuan media ular tangga dapat meningkatkan keterampilan Collaborative siswa pada mata pelajaran matematika. Oleh karena itu peneliti menyarankan agar guru menggunakan model Teams Games Tournament berbantuan media ular tangga sebagai alternatif strategi baru dalam proses kegiatan belajar mengajar di dalam kelas. Bagi kepala sekolah agar memfasilitasi guru dalam menggunakan model Teams Games Tournament berbantuan media ular tangga dalam meningkatkan mutu pendidikan di sekolah.

\section{DAFTAR PUSTAKA}

Adam, \& Hams. (2010). Pembelajaran Matematika Untuk SD. Jakarta: Erlangga.

Afandi, R. (2015). Pengembangan Media Pembelajaran Permainan Ular Tangga Untuk Meningkatkan Motivasi Belajar Siswa Dan Hasil IPS di Sekolah Dasar. Jurnal Inovasi Pembelajaran, 1(1), 77-89.

Fauzi, M. (2017). Peningkatan Kerjasama Dan Prestasi Belajar Matematika Materi Bangun Datar Melalui Model Pembelajaran Kooperatif Tipe Team Game Tournament (TGT) Di Kelas IV Sekolah Dasar (Doctoral Dissertation, Universitas Muhammadiyah Purwokerto).

Ferryka, P. Z. (2017). Permainan Ular Tangga dalam Pembelajaran Matematika di Sekolah Dasar. Magistra, 4(2), 59-62.

Ibrahim, \& Suparni. (2015). Pengajaran Matematika. Jakarta: Karunika.

Mawardi. (2018). Merancang Model dan Media Pembelajaran. Scholaria: Jurnal Pendidikan Dan Kebudayaan, 8(1), 26-40.

Mawardi, M. (2014). Pemberlakuan Kurikulum SD/MI Tahun 2013 dan Implikasinya Terhadap Upaya Memperbaiki Proses Pembelajaran Melalui PTK. Scholaria: Jurnal Pendidikan Dan Kebudayaan, 4(3, 107-121.

Trianto. (2009). Mendesain Model Pembelajaran Inovatif-Progresif Konsep, Landasan, dan Implementasinya Pada Kurikulum Tingkat Satuan Pendidikan (KTSP).Jakarta: Kencana Prenada Media Group.

Yudianto, W. D., Sumardi, K., \& Berman, E. T. (2014). Model Pembelajaran Teams Games Tournamen Untuk Meningkatkan Hasil Belajar Siswa SMK. Journal of Mechanical Engineering Education, 1(2), 323320. 
Nopiani, N. M. E., Meter, I. G., \& Wiarta, I. W. (2013). Model Pembelajaran Tgt Berbantuan Media Permainan Ular Tangga Berpengaruh Terhadap Hasil Belajar Matematika Siswa Kelas IV SD Gugus VIII Sukawati. Mimbar Pgsd Undiksha, 1(1), 74-83.

Negeri, K. V. S. (2016). Pengaruh Model Pembelajaran Kooperatif Tipe Team Games Tournament (TGT) dan Aktivitas Setting Lingkungan Terhadap Hasil Belajar Siswa dalam Mata Pelajaran Ipa Kelas VI SD Negeri 002 Rambah Kabupaten Rokan Hulu. Jurnal Ilmiah Edu Research Vol, 5(1), 5. 